\title{
Preparation and Marketing of Granulated Panela in Family Businesses from Caluma (Ecuador)
}

\author{
Riveliño Ramón ${ }^{1}$, Katherin Beltrán ${ }^{1}$, Luis Verdezoto ${ }^{1}$, Angel Remache ${ }^{2}$, Favian Bayas-Morejón ${ }^{1, *}$ \\ ${ }^{1}$ Department of Postgraduate and Continuing Education, Faculty of Agricultural Sciences, Bolivar State University, Guaranda, Ecuador \\ ${ }^{2}$ Unidad Educativa Guaranda, CP: 020150, Guaranda, Ecuador
}

Received September 25, 2020; Revised December 7, 2020; Accepted December 13, 2020

\section{Cite This Paper in the following Citation Styles}

(a): [1] Riveliño Ramón, Katherin Beltrán, Luis Verdezoto, Angel Remache, Favian Bayas-Morejón, "Preparation and Marketing of Granulated Panela in Family Businesses from Caluma (Ecuador)," Food Science and Technology, Vol. 8, No. 4, pp. 73-78, 2020. DOI: 10.13189/fst.2020.080401.

(b): Riveliño Ramón, Katherin Beltrán, Luis Verdezoto, Angel Remache, Favian Bayas-Morejón (2020). Preparation and Marketing of Granulated Panela in Family Businesses from Caluma (Ecuador). Food Science and Technology, 8(4), 73-78. DOI: 10.13189/fst.2020.080401.

Copyright $\odot 2020$ by authors, all rights reserved. Authors agree that this article remains permanently open access under the terms of the Creative Commons Attribution License 4.0 International License

\begin{abstract}
For decades, the canton Caluma has maintained its traditions in the cultivation and obtaining of the production derived from the cane of sugar, as well as in the commercialization of the same one. So, the objective of this work was to identify opportunities for improvement of the production and marketing processes of granulated panela in family businesses in canton Caluma, for which a field investigation was applied, surveys (face-to-face surveys) with open and closed questions were applied to a population of 60 farmers. Methods were used: Inductive, Deductive, Synthetic Descriptive and Statistical. The results of the field diagnosis showed that $35 \%$ of farmers are illiterate, $40 \%$ middle school and $35 \%$ higher education, more than $50 \%$ of farmers account for between 1 and 4 hectares of land, the $70 \%$ of the producers are associated, $28 \%$ generated by-products (block panela, $47 \%$ burning water and $25 \%$ granulated panela). Most of the production is sold in local markets with $48 \%$ in the cities of Caluma, Guaranda or Chimbo (Ecuador). With the improvements in the commercialization chains, it is estimated that the most interested would be: CIBVS Children's Centers, Fundación Maquita, CAMARI, Bolivar brand, Supermarkets and local stores. According to the analysis, the elasticity of demand is 1.16 , with a profit margin of $73 \%$ in high season and $43 \%$ in low season. The sales strategy that is sought to be implemented is to have a number of fixed customers that constantly place orders, whether weekly or monthly, before distributing through an operating system.
\end{abstract}

Keywords Marketing, Granulated Panela, Businesses,
Ecuador

\section{Introduction}

Globally, the cultivation of sugarcane (Saccharum officinarum) has become very important, since by-products such as granulated panela can be obtained, having an approximate production of 1,550 million tons and about 22 million hectares cultivated. Among the countries with the highest production worldwide, it tops the list Brazil followed by India and China [1].

At the agricultural level, problems of cultivation, yield, cane varieties, soluble solids and maturity are evident. Regarding the industrialization field, technology problems stand out where rudimentary and artisanal processes that affect the quality and safety of the product prevail. Waste management affects the environment, caused by the non-application and poor control of standards [2]. The sugar industry in our country is very significant in terms of the economic development of the lowlands in the provinces of Guayas, Cañar, Santa Elena and Los Ríos, to a lesser extent in Bolívar and this in turn contributes to the production of sugar destined to human consumption. The percentage with which this industry contributes to the national gross domestic product is $1.4 \%$, creating around 30,000 direct and 80,000 indirect jobs in times of greatest production $[3 ; 4]$. Sugarcane production has achieved a 
significant increase in 2017. 116,000 hectares were sown compared to 109,000 in the previous year, with a growth of $6.03 \%$. This has contributed enormously to the development of the popular economy, from this point of view, the Organic Law of Popular and Solidarity Economy is in the form of an economic organization where its members individually or collectively organize and develop processes of exchange production, commercialization, and consumption of goods and services to satisfy needs and generate income [5]. Although, to achieve this, a collective education is very important, specifically aimed at a product marketing activity, because good production can be obtained, but if marketing and commercialization is unknown, the desired achievement cannot be obtained [6].

The province of Bolívar is located in the number seven position within the ten cane producing provinces, its highest productivity is $50 \mathrm{Tm}$ per hectare, while in the mills it is $105.9 \mathrm{Tm}$ per hectare and the sugar producers produce 103.4 Tm per hectare (Table 1).

Table 1. Sugarcane production in the province of Bolívar

\begin{tabular}{cccccc}
\hline \multirow{2}{*}{ Year } & Canton & $\begin{array}{c}\text { Harvested } \\
\text { Surface } \\
(\text { Ha) }\end{array}$ & $\begin{array}{c}\text { Harvested } \\
\text { production }\end{array}$ & $\begin{array}{c}\text { Yield } / \\
\text { Ha }\end{array}$ & $\begin{array}{c}\text { Provincial } \\
\text { Percentage }\end{array}$ \\
\hline \multirow{2}{*}{2017} & Caluma & 220 & 80400 & 365.45 & 9.30 \\
\cline { 2 - 6 } & Echeandía & 367 & 149450 & 407.22 & 15.51 \\
\cline { 2 - 6 } & Guaranda & 932 & 472250 & 506.71 & 39.39 \\
\cline { 2 - 6 } & Las Naves & 11 & 2180 & 198.18 & 0.46 \\
\cline { 2 - 6 } & Chimbo & 159 & 67606 & 425.19 & 6.72 \\
\cline { 2 - 6 } & $\begin{array}{c}\text { San } \\
\text { Miguel }\end{array}$ & 677 & 276204 & 407.98 & 28.61 \\
\hline
\end{tabular}

Source: Ministry of Agriculture and Livestock (MAG) of Bolívar, 2017.

Based on information from the Ministry of Agriculture and Livestock (MAG) of the Bolivar province, the highest percentage of sugarcane cultivation is the canton Guaranda with $39.39 \%$ followed by the San Miguel with 28.61, Echeandía with 15.51, Caluma with 9.30, Chimbo with 6.72 and finally Las Naves with $0.47 \%$.

For decades, the canton Caluma has maintained its traditions in the cultivation and obtaining of the production derived from the cane of sugar, as well as in the commercialization of the same one. Despite the undeniable improvement in production and productivity for sugarcane derivatives, marketing remains a problem, as producers continue to market their products individually.

Based on information recorded at the Central Bank of Ecuador, it can be observed that granulated panela exports keep encouraging figures being very popular at national and international level, among the countries of destination of exports are: Italy, Spain, Germany, Netherlands, France, Colombia and the United Kingdom [7].

The objective was to identify opportunities to improve the production and marketing processes of granulated panela in family businesses in the canton Caluma (Ecuador).

\section{Materials and Methods}

\section{A Field Investigation Was Applied}

To obtain information necessary for the study, surveys were applied to the active producers in the area and to the merchants.

The survey was based on face-to-face or in-depth work, since it allowed guiding and advising the respondent. The types of questions used in the survey were open and also closed, which are of a single choice (politomic).

Observational Through the observation, the behavior of the different agents involved in the production and commercialization processes was described and explained.

Explanatory it is used in order to determine the causes and consequences of the problem under study. Obtaining qualitative and quantitative data from the application of surveys, the information related to the production and marketing of granulated panela in Caluma was established.

The methods used for the development of this research were: Inductive, Deductive, Synthetic Descriptive and Statistical. Table 2 shows the study of the population of sugarcane producers.

Table 2. Study population

\begin{tabular}{ccccc}
\hline & \multicolumn{4}{c}{ sugarcane producers } \\
\cline { 2 - 4 } Canton & Small & medium & Total & $\%$ \\
Caluma & producers & producers & 60 & 100 \\
\hline
\end{tabular}

\section{Results}

Analysis of surveys of granulated panela producers, through the field work carried out, a 50\% gender participation for both men and women of a total of 60 respondents was considered.

The population of the Caluma canton according to the 2010 census represents $6.5 \%$ of the total of the Bolivar province. $59 \%$ reside in the rural area; it is characterized by being a young population since $44.9 \%$ are under 20 years old, and the population by sex of men $50.3 \%$ and women $49.7 \%[8]$.

\section{Education Level}

In the field diagnosis, it was determined that $35 \%$ of farmers are illiterate, $40 \%$ have primary education; while they have had access to higher education barely $3 \%$.

\section{Land Tenure}

In relation to land ownership, more than $50 \%$ of 
farmers account for between 1 and 4 hectares of land (Table 3).

Table 3. Land tenure

\begin{tabular}{ccc}
\hline HAS. & $\mathbf{N}^{\mathbf{0}}$ & $\mathbf{\%}$ \\
\hline Less than 1Ha. & 6 & 10 \\
From 1 to 4 Ha. & 31 & 51.67 \\
More than 5 Ha. & 13 & 38.33 \\
\hline TOTAL & 60 & 100 \\
\hline
\end{tabular}

The $70 \%$ of farmers are associated in different ways, while $30 \%$ of families do not belong to associative groups, they work on their own; the association that concentrates the largest number of families is the so-called "FLOR DE CAÑA".

\section{Cane by Products}

About $30 \%$ of the farmers produce brown sugar in block; however, almost $50 \%$ of these are dedicated to producing burning water (Table 4).

Table 4. Derivatives of cane

\begin{tabular}{ccc}
\hline Derived & $\mathbf{N}^{\mathbf{0}}$ & $\mathbf{\%}$ \\
\hline Panela in block & 17 & 28 \\
Schnapps & 28 & 47 \\
Granulated panela & 15 & 25 \\
\hline TOTAL & 60 & 100 \\
\hline
\end{tabular}

The $88.83 \%$ of families produce panela two or three times a year, while $12 \%$ produce once a month. None of the families surveyed produce granulated panela a week since this work takes too much time (at times that go from 5 am to $6 \mathrm{pm}$ ). This work is carried out mainly in the summer season with an average of 2 harvests; the yield in the winter season is lower.

Most of the producers (58\%) use mixed methods (traditional and technical) in the production of sugarcane, while $37 \%$ do so only by hand.

\section{Analysis of Supply and Demand}

\section{Production Scale}

The national production of sugar is mostly destined for the domestic market, since according to the Ministry of Agriculture and Livestock (MAG), the minimum support price for the metric ton of sugarcane is USD 32.20. In Ecuador, there are 74,000 hectares of sugarcane, of which $50 \%$ belongs to the mills and the other $50 \%$ is distributed among the 3000 small and medium producers. [9].

\section{Offer of Granulated Panela}

The approximate production of granulated panela of the families under study is $259,000 \mathrm{~kg}$, which are offered in the fairs of the city and nearby towns and intermediaries.

\section{Marketing Channels}

Most of the production is sold in local markets with $48 \%$ in the cities of Caluma, Guaranda or Chimbo (Ecuador). $45 \%$ of the production is delivered to the different collection centers or intermediaries and $7 \%$ is sold in the same sector (farm).

There are currently buyers or claimants of the product. Once improved its quality, the main markets interested would be:

\section{- CIBVS Children's Centers}

- MCCH (Maquita Foundation) Marketing as Brothers

- CAMARI that works with all the stores of popular organizations

- Marketing centers of the Provincial Council of Bolivar (Marca Bolívar)

- Supermarkets and local stores

\section{Price Elasticity}

According to the analysis, the elasticity of demand is 1.16 , this means that we have an elastic demand. When having an increase in the price, the answer will be a variation more than proportional in the quantity demanded, moving away some consumers that will be able to replace the product by other substitute goods. In the same way, the profitability of granulated panela per $1 \mathrm{Kg}$ of production is shown in table 5.

Table 5. Profitability of the production $(1 \mathrm{~kg})$ of granulated panela

\begin{tabular}{ccc}
\hline Profitability & High season low & Low season \\
\hline production cost for $1 \mathrm{~kg}$ & 1.26 & 1.26 \\
Price & 1.8 & 3.25 \\
$(=)$ Beneficio & 0.54 & 1.99 \\
\hline Profitability margin & $43 \%$ & $73 \%$ \\
\hline
\end{tabular}

\section{Proposal}

Producers will have a buyer that guarantees a price and profitability and buyers will have a quality product and the safety they need.

The association that is legally constituted is aimed at obtaining the FLOR DE CAÑA patent, and the following objectives will be considered.

- Create the association's own brand.

- Streamline marketing with technological means

- Describe functions and procedures of the web platform.

\section{SWOT Analysis}

\section{Strengths}

- Granulated panela is desired for its nutritional properties. 
- Producers with experience in the production of panela.

- Ability to form fundamental marketing systems

- Technical advice received from foundations and government entities.

- Association in the process of organic certification.

- Closeness to the target markets.

- Proximity to a road that communicates between the mountains and the coast of Ecuador.

\section{Weaknesses}

- Inadequate communication routes for the transfer of production.

- Most growers do not have stainless steel equipment.

- There is no technification in the facilities of the sugar growers.

- Demotivation of the partners due to existing problems in marketing.

- High production costs due to failures in the transformation process (raw material).

- Quality of the panela not in accordance with the market requirement.

- Personnel not trained to handle productive costs, quality control and sales.
The product does not have organic or fair-trade certification.

\section{Opportunities}

- Progressive interest in the organic products market.

- High price for the sale of the product in bulk.

- Attractive prices for direct sale to the final consumer.

- Municipality of Caluma with predisposition to cooperate with the association.

\section{Threats}

- Decrease in prices of panela sold in bulk.

- Very long or rainy winter season that makes it difficult to use the access roads.

- Attrition of members of the association due to lack of perceived benefits.

\section{Identification of needs and measures to be taken}

The list of needs and measures to take are shown in table 6, on the other hand, the marketing methods can be seen in table 7 and the organizational mechanism in table 8 .

\section{Production}

Table 6. Needs and measures to take

\begin{tabular}{c|ll}
\hline Needs & & Measures to take \\
\hline Improved quality of granulated panela & - & Technical analysis of the production process \\
Optimize the use of resources in production & - & Constant training to partners on good production and manufacturing practices. \\
Constant supply of raw material & - & Improve infrastructure to make the production process faster and incur less labor use \\
Reduce production costs & - & Improvement of access roads. \\
Increase in production volume & - & Tse of the cane produced by the partners of nearby properties \\
Quality control & - & Records and Control of the use of resources and efficiency of the process \\
& $-\quad$ Ancrease in available raw material. \\
& $-\quad$ Train a person to handle the quality control of production
\end{tabular}

Table 7. Commercialization

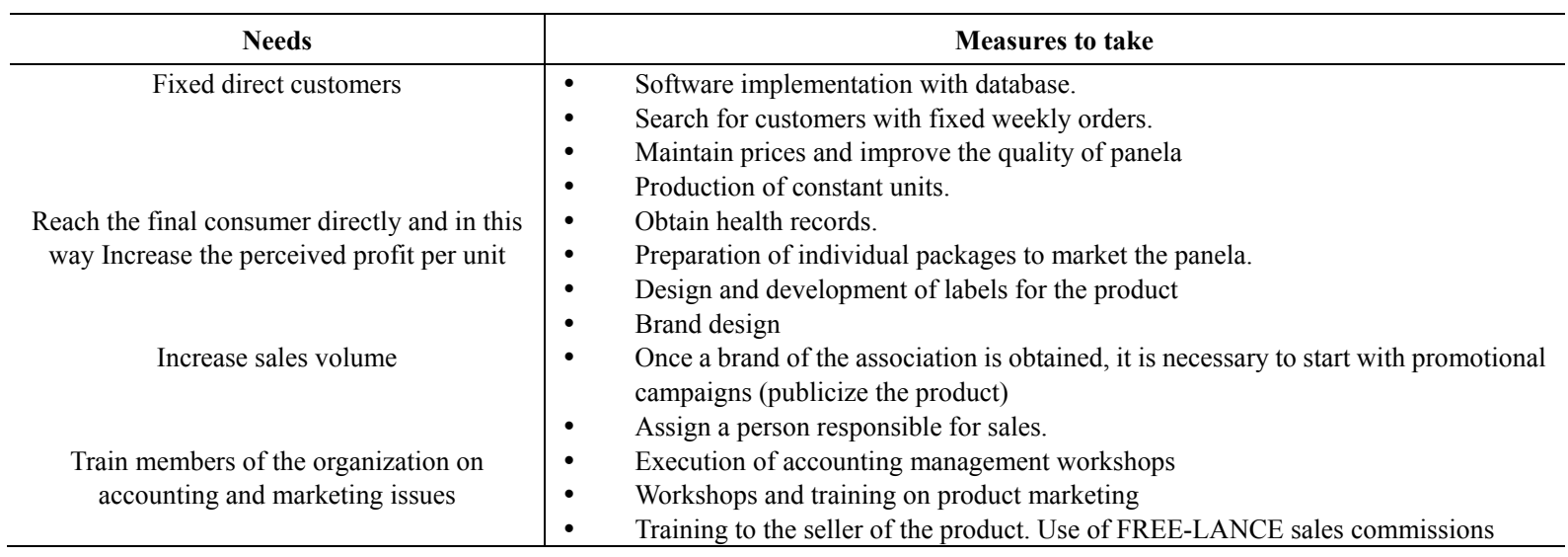


Table 8. Organizational

\begin{tabular}{ll}
\hline \multicolumn{1}{c}{ Needs } & \multicolumn{2}{c}{ Measures to take } \\
\hline $\begin{array}{l}\text { Arreglar situación de la } \\
\text { asociación con el S.R.I }\end{array}$ & $\begin{array}{l}\text { Carry out the necessary } \\
\text { procedures to keep the } \\
\text { association's obligations up to } \\
\text { daternal Revenue Service, } \\
\text { Ecuador) }\end{array}$ \\
$\begin{array}{l}\text { process of obtaining health } \\
\text { records }\end{array}$ \\
$\begin{array}{l}\text { Hold meetings in order to } \\
\text { motivate the members of the } \\
\text { association } \\
\text { Increase the motivation and } \\
\text { of the association }\end{array}$ \\
$\begin{array}{l}\text { Increase panela orders } \\
\text { To inform the members of the } \\
\text { association about improving the } \\
\text { functioning of the association. }\end{array}$ \\
\hline
\end{tabular}

Strategy: The sales strategy to be implemented is to have a number of fixed customers that constantly place orders, whether weekly or monthly, before distributing through an operating system. With this, it is certain that the production will be purchased, constituting a motivation for the producer, in addition to generating long-term relationships of trust with these customers.

\section{Web environment/ clients}

This environment was created for the entry of our customers from the web, through which you can enter your orders and register your different points of sale (Figure 1).

\section{Promotion}

The promotion of granulated panela using the product brand will seek to persuade the consumer to purchase informing of the benefits of the consumption of panela, its way of use, through a lower price in relation to competition (Figure 2), focused on the associative work carried out with support to small producers and using organic certification. Another form of promotion is the participation in food fairs nationwide organized by the private company or by the government.

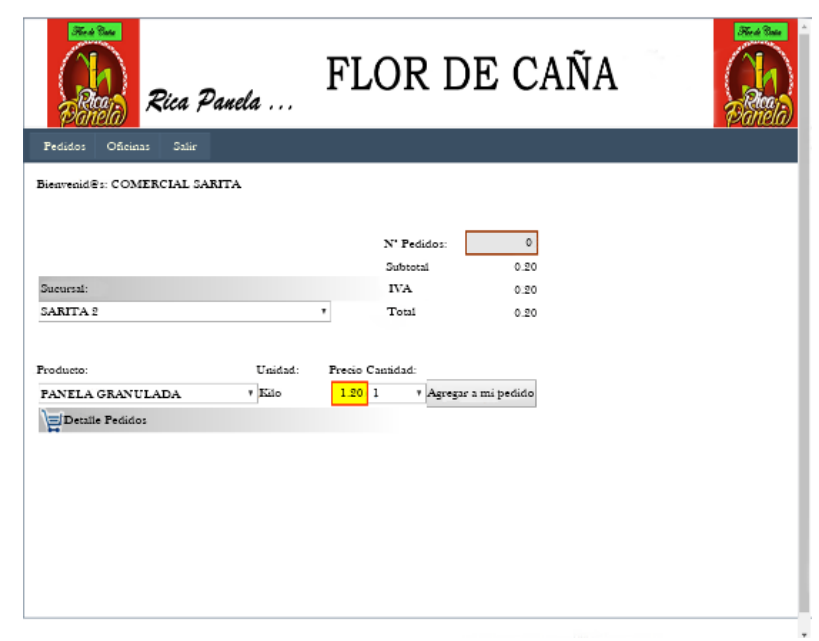

Figure 1. Web environment

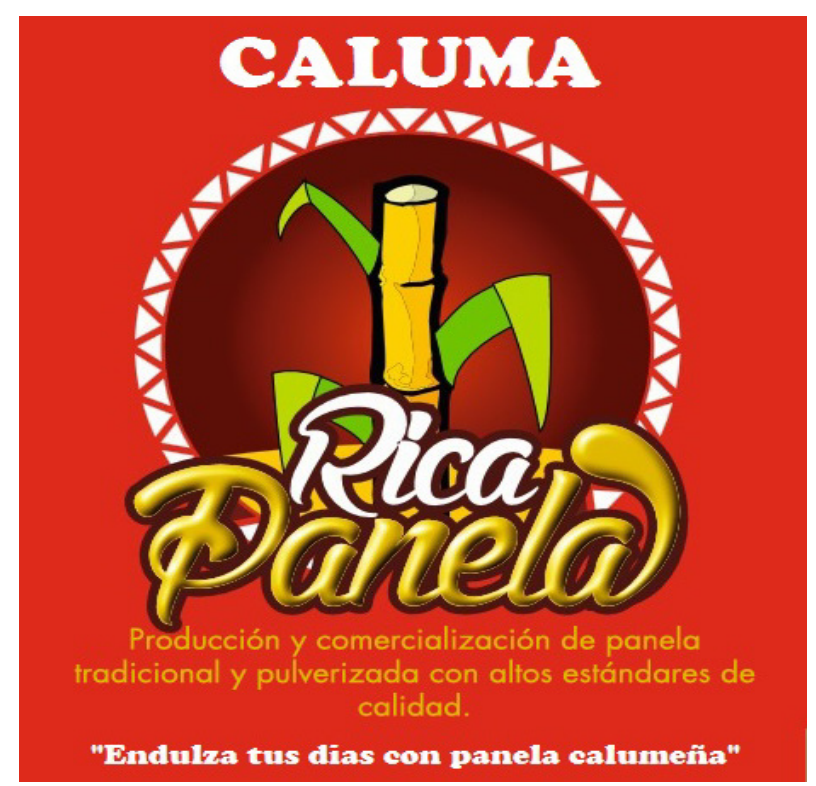

Figure 2. Product label

\section{Conclusions}

It is concluded that despite the existence of perfectly established legal associative organizations in the study area, the confidence of the producers is negative since they have not fulfilled the proposed purposes, maintaining a weakened organizational system that they have been enduring for several years.

\section{Acknowledgments}

Full thanks to the Association of Sugar Cane Producers of the Caluma Canton (Ecuador), as well as to the Postgraduate Department of the State University of Bolívar for the support provided in this work.

\section{REFERENCES}

[1] D. Zhao, and Y-L. Li, "Climate Change and Sugarcane Production: Potential Impact and Mitigation Strategies", International Journal of Agronomy, Article ID 547386, pp 10, 2015. https://doi.org/10.1155/2015/547386.

[2] W. Quezada. "Guía técnica de Agroindustria Panelera", Repositorio Universidad Técnica del Norte, pp 60, 2012.

[3] MAGAP. Ministerio de Agricultura, Ganadería, Acuacultura y Pesca, "Programa buen vivir rural", pp 1, 2017.

[4] INEC. Instituto Nacional de Estadísticas y Censos, Estadística Agropecuaria ESAG, "Superficie de Producción2, pp 24, 2016.

[5] U. Barragán Vinueza, R. Ramón, J L. Altuna, F. Bayas-Morejón. "Ancestral Practice in the Production of 
Cheeses, Attends the Health and Good Living of the Consumer in San Pablo De Atenas, Province of Bolivar (Ecuador)". Advances in Economics and Business, 8(1), 28 31. 2020. DOI: 10.13189/aeb.2020.080103.

[6] S. Egüz, C. Öztürk, A. Kesten. "A Global Education Application in Turkey: A Product Marketing Activity," Universal Journal of Educational Research, Vol. 6, No. 4, pp. 638 - 646. 2018. DOI: 10.13189/ujer.2018.060407.
[7] L. Nastul. "Exportación de panela molida a Alemania, Trabajo de titulación previo a la obtención de Tecnóloga en exportaciones e importaciones", Universidad de las Américas (UDLA), pp 60, 2017.

[8] INEC. Instituto Nacional de Estadísticas y Censos, "Reporte estadístico del sector agropecuario”, pp. 49, 2011.

[9] MAG. Ministerio de Agricultura, Ganadería, "Superficie de Labor Agropecuaria", 2018. 